\title{
Colon Cancer and Swimming Exercise: Effect on Wistar Rat Testes
}

\author{
Karine Moura de Freitas ${ }^{1 *}$, Antônio José Natali ${ }^{2}$, Wellington Lunz ${ }^{3}$, Kyvia Lugate Cardoso \\ Costa $^{4}$, Rodrigo Paula Leite ${ }^{1}$, Heidi Dolder ${ }^{1}$ and Sérgio Luis Pinto da Matta ${ }^{4}$ \\ ${ }^{1}$ Departamento de Biologia Estrutural e Funcional; Instituto de Biologia; Universidade Estadual de Campinas; \\ Campinas - SP - Brasil. ${ }^{2}$ Departamento de Educação Física; Centro de Ciências Biológicas e da Saúde; \\ Universidade Federal Viçosa; Viçosa - MG - Brasil. ${ }^{3}$ Departamento de Desportos; Centro de Educação Física e \\ Desportos; Universidade Federal do Espírito Santo; Vitória - ES - Brasil. ${ }^{4}$ Departamento de Biologia Geral; Centro \\ de Ciências Biológicas e da Saúde; Universidade Federal de Viçosa; Viçosa - MG - Brasil
}

\begin{abstract}
This study was undertaken to determine whether colon cancer $(C C)$ and chronic swimming exercise alter rat testis. Eleven weeks old rats were distributed into control group $(n=6)$ and the groups that were induced to develop CC by dimethylhydrazine injections ( $n E G, E G 0, E G 2$ and EG4; $n=10$ each group). In the group $n E G$, the rats did not swim, whereas groups EG0, EG2 and EG4, underwent a swimming program with distinct loads (0, 2 and $4 \%$ of body mass, respectively) for 35 weeks. The morphometry, stereology and cell counts showed damage caused by the CC on the germ epithelium. These results were noteworthy since this was the first report to associate the CC with testicular damage. Swimming exercise had no significant role in reducing, or increasing the CC effects on the testis, despite having slightly improved the testis structure of the exercised rats without load. In conclusion, CC caused testis impairment, which could not be avoided by the swimming exercise.
\end{abstract}

Key words: 1,2-dimethylhydrazine, fertility, reproduction, spermatogenesis

\section{INTRODUCTION}

Most of the gut tumors have an epithelial origin and $98 \%$ of colon cancers are adenocarcinomas (Cotran et al. 1996). Several risk factors are associated with the development of colon cancer, which include the family history of colon cancer, smoking, excessive alcohol ingestion and sedentarism (Friedenreich and Orenstein 2002; Harriss et al. 2009). Many studies have shown the influence of physical exercise on the decrease of colon cancer incidence (Friedenreich and Orenstein 2002; Demarzo et al. 2008; Lunz et al. 2008). Demarzo et al. (2008) showed that moderate chronic swimming exercise was antiproliferative and antinflammatory for the rat colon cells. In contrast to moderate exercise, acute exhaustive swimming is associated with the increased colon cancer susceptibility in the rats, which is likely to be due to increased production of reactive oxygen species (Demarzo and Garcia 2004).

Further studies have also demonstrated a relation between the exercise intensity and the impairment of male fertility. Reduction in the basal and total testosterone level was observed after intensive endurance exercise in the humans, which could possibly lead to the disruption of testosterone dependent processes (Manna et al. 2003; Hackney 2008; Jana et al. 2008). Also, intensive swimming

*Author for correspondence: karinemfreitas@gmail.com 
exercise has been linked to a vast range of impairments regarding the male fertility, such as reduced spermatic production (Mingoti et al. 2003), reduced somatic index of the testes, epididymis, prostate and seminal vesicle (Manna et al. 2003), reduced number of preleptotine spermatocytes, midpachytene spermatocytes and stage 7 spermatids (Manna et al. 2003; Jana et al. 2008), and reduced epididymal sperm count (Jana et al. 2008). As observed for the increased colon cancer susceptibility, the damages caused to male fertility by the exercise appear to be associated with an increase in oxidative stress (Manna et al. 2003; Manna et al. 2004).

Animal models are indispensible for cancer research, and chemical induction is the most common method used for developing the colon cancer (Hoffman-Goetz 2003). 1,2dimethylhydrazine $(\mathrm{DMH})$ is widely used for colon cancer induction. It causes DNA hypermethylation of the colon cells (HoffmanGoetz 2003). Most studies of cancer have been carried out to clarify the molecular and structural development of the cancer and possible treatments. However, the study of the consequences of cancer in the organs other than those directly affected by this disease has not been commonly undertaken. The present study was designed to analyze whether colon cancer caused damage to the testis, an organ not directed related to the disease, and determine if long term swimming exercise could reduce these effects.

\section{MATERIALS AND METHODS}

\section{Experimental Animals}

Male Wistar rats (Rattus norvegicus) were obtained from the Central Animal House (Federal University of Viçosa, Viçosa, MG, Brazil). They were maintained under standard conditions of luminosity (dark $12 \mathrm{~h} / 12 \mathrm{~h}$ light) and temperature and provided with commercial chow and water $a d$ libitum. The experimental protocol was approved by the Animal Care and Use Committee of the Federal University of Viçosa, MG, Brazil.

\section{Colon cancer induction}

Colon cancer was induced by the application of four subcutaneous injections of 1,2dimethylhydrazine (DMH, Sigma, USA) as previously described by Lunz et al. (2008). Two injections were given in the first week and the others in the second week on nonconsecutive days. The DMH $(40 \mathrm{mg} / \mathrm{kg})$ was dissolved in $0.9 \% \mathrm{NaCl}$ containing $1.5 \%$ EDTA as a vehicle so that the final concentration was $10 \mathrm{mg} / \mathrm{mL}$ and the $\mathrm{pH} 6.5$.

\section{Treatment protocols}

Eleven week old rats were randomly divided into five groups. The control group (CG) $(n=6)$ was not submitted to DMH-injections nor swimming exercise. The group that was not exercised (nEG; $n=10$ ) was only injected with DMH. The other groups were DMH-injected and submitted to swimming training during 35 weeks either without load (EG0), with $2 \%$ of body mass load (EG2), or with $4 \%$ of body mass load (EG4). The exercised animals swam 5 to $15 \mathrm{~min} /$ day, 5 days/week, during the first two weeks, without a load. From this period to week 5 , the animals swam with their respective loads for 5 to $20 \mathrm{~min} /$ day, 5-days a week. From week 5 to the end of the experiment, the animals swam with their respective loads for 20min/day for 5 days/week (Lunz et al. 2008). The swimming tanks where the rats were exercised were filled with water to a depth of $45 \mathrm{~cm}$ and maintained at $28-30^{\circ} \mathrm{C}$. The rats from the groups CG and nEG stayed in a tank filled with water to a depth of $10 \mathrm{~cm}$ during the same amount of time as the exercised animals' swimming session.

\section{Euthanasia, tissue collection and biometry}

At the end of the treatment, the rats were euthanized by carbon dioxide asphyxia and weighed. Testes and epididymis were collected and weighed. The tunica albuginea was removed from only one testis to obtain the weight of testicular parenchyma and albuginea. The gonadosomatic index (GSI) was calculated as a percentage of body mass represented by the testes [GSI $=$ Testes weight $\mathrm{x} 100 /$ body weight] (Monteiro et al. 2008; Costa et al. 2011; Freitas et al. 2011; Gomes et al. 2011)

\section{Preparation of tissue for light microscopy}

One testis was dissected and fixed in 10\% formalin. Testicular fragments were dehydrated and embedded in hydroxyethyl methacrylate (Historesin ${ }^{\circledR}$, Leica). Sections (3 $\mu \mathrm{m}$ thick) were obtained and stained with toluidine blue/1\% sodium borate (Monteiro et al. 2008; Costa et al. 2011; Freitas et al. 2011; Gomes et al. 2011). 


\section{Morphometry and stereology}

All the following measurements were made according to previous studies Monteiro et al. 2008; (Leite et al. 2010; Predes et al. 2010; Costa et al. 2011; Freitas et al. 2011). The images were captured with an Olympus-AX70 light microscope and the morphometrical and stereological analyses were performed using Image-Pro Plus 4 software. A grid with 494 points was used to estimate the volumetric proportion $(\%)$ of the testicular parenchyma elements (seminiferous tubules and interstitial tissue) and the percentage of the points on each component was calculated. Ten randomly captured images, using 200x magnification, were used to count a total of 4940 points per animal. The volumetric proportion (\%) of the elements of interstitial tissue (Leydig cells - nucleus and cytoplasm, connective tissue cells and fibers, blood vessels, lymphatic space and macrophages) was determined by the count of 1000 points in the intertubular compartment for each animal (400x magnification).

The total volume of each testicular component, expressed in $\mathrm{mL}$ was estimated multiplying the volumetric proportion of each component by the testicular volume and the result was divided by 100. Testicular density is around 1 (França 1991), thus, the testicular parenchyma volume had the same value as its weight. Tubule-somatic index (TSI) was calculated by the ratio between the seminiferous tubule volume and body mass, the result being multiplied by 100 (Costa et al. 2011; Freitas et al. 2011; Gomes et al. 2011). The tubular diameter was measured in 10 seminiferous tubule sections with circular transections. In the same sections, two perpendicular epithelium thicknesses were measured from the tunica propria to the lumen. The average tubular diameter and thickness of the seminiferous epithelium was calculated for each animal.

The total length of seminiferous tubules was estimated, in meters, from the volume occupied by seminiferous tubules in the testes and the mean tubular diameter for each animal (Attal and Courot 1963; Dorst and Sajonski 1974). Nuclear and cytoplasmatic volumetric proportions (\%) of Leydig cells (LC) were estimated by counting 500 points upon nuclei and cytoplasm of this cell, using the images obtained with 400x magnification. The mean diameter of LC nuclei was estimated by the measurement of 30 nuclear diameters per rat, in the same images as counted above. The nuclear volume was calculated by the formula $4 / 3 \pi r^{3}$, in which " $r$ " corresponded to the nuclear radius. Nuclear volume and nucleus/cytoplasm proportion was used to obtain the cytoplasm and individual volume of LC. LC number was estimated by the total volume occupied by these cells in the testis divided by the individual volume of LC. Leydig-somatic index (LSI) was calculated by the ratio between the volume occupied by LC compared to the testis and the body mass, the result being multiplied per 100 (Freitas et al. 2011).

\section{Quantification of Sertoli and germ line cells}

The Sertoli cell (SC) nucleoli and nuclei of spermatogonia A, preleptotone and pachytene spermatocytes and round spermatids were counted in 10 circular seminiferous tubule sections in stage I per rat with 200x magnification to estimate the population of these cells (Swierstra 1968; Curtis and Amann 1981; Amann and Schanbacher 1983). The mean nuclei and nucleoli diameters, the latter for Sertoli cells, were obtained by measuring 30 nuclei (or nucleoli) of each stage of germ cell cited above. These counts were corrected for section thickness and nucleus, or nucleolus diameter (Amann and Almquist 1962). Using the corrected counts of germ and Sertoli cells, some indices were calculated: the coefficient of spermatogonial mitosis efficiency or mitotic yield (preleptotene spermatocytes / spermatogonia A); spermatogenesis yield (round spermatids/ spermatogonia A); meiotic yield (round spermatids /pachytene spermatocytes); and the Sertoli cell supporting index (germ line cell number / Sertoli cell number). The total number of $\mathrm{SC}$ was determined from the corrected counts of SC nucleoli per seminiferous tubule cross-section and the total length of the seminiferous tubule, according to Hochereau-de Reviers and Lincoln (1978). The SC number per gram of testis was obtained from the ratio between the total number and the testis weight.

\section{Statistical analysis}

The averages were compared among the experimental groups by ANOVA post hoc with Duncan's test (using the software STATISTICA for WINDOWS 3.11); the values of $p<0.05$ were considered significant. All data are presented as mean \pm standard deviation (SD). 


\section{RESULTS AND DISCUSSION}

This is the first study that correlated the DMHinduced colon cancer and testicular structure and the effect of a long-term swimming program on the testis of Wistar rats with colon cancer. The colon cancer is associated with a good prognostic and possibilities of cure. Hence, the study of the impairment caused by this disease on testis structure was a contribution toward the future research looking for the ways to reduce this damage and maintain male fertility after cancer treatment. Previous studies have shown reduction of colon cancer incidence with exercise (Friedenreich and Orenstein 2002; Demarzo et al. 2008; Lunz et al. 2008). Hence, it was considered as important to investigate if regular swimming exercise attenuated, or accentuated the testicular impairment caused by the colon cancer in Wistar rat testes.

The tumor incidence (rats with one or more tumors) was $0,90,72.7,90.9$ and $80 \%$ in the groups CG, nEG, EG0, EG2 and EG4, respectively (data previously published by Lunz (2006)). The rats with induced colon cancer development (groups nEG, EG0, EG2 and EG4) presented a significant reduction in body weight when compared to the controls (Table 1). This reduction was probably caused by the cancer cachexia, a state presented by the individuals with malignant tumors and characterized by anorexia, anemia, loss of weight and tissue mass (Ockenga and Valentini 2005; Silva 2006).

Epididymis weight was higher in the animals affected by the colon cancer, when compared to the control group (Table 1). Some studies have shown that colon cancer causes metastasis with the appearance of epididymis adenocarcinoma (Kanno et al. 1994; Moreno et al. 2005; Janeiro Pais et al. 2006). The increase in epididymis weight of the rat with colon cancer could be due to the development of adenocarcinoma in this organ. However, a histophatological analysis of epididymal tissue was not made. Testicular weight reduction observed in the groups with cancer when compared with the control group was due to reduction of testicular parenchyma weight, since the albuginea weight did not present significant variation (Table 1). The testicular parenchyma was the functional portion of the testis and this reduction could suggest damage to spermatogenesis of the rats with colon cancer. The GSI quantifies the percentage of the testes in relation to body weight. The increase of this parameter in the exercised groups was due to body weight reduction, when compared to the controls. Similarly, the TSI increase (Table 2) could be explained in the same way for the exercised groups in relation to the control.

No alteration in volumetric proportion of both seminiferous tubules and interstitial tissue was observed (Table 2). The reduction of the seminiferous tubule volume in the groups that received DMH injections was reflected in the reduction in the total length of seminiferous tubules, since there was no significant alteration of tubular diameter (Table 2). Russell and Franca (1995) integrated data on testicular compartments from the literature and demonstrated that the seminiferous tubule volume in a normal rat testis could vary from 1.099 to 1.720 . Thus, the volume of seminiferous tubule in the control group was considered normal $(1.14 \pm 0.04)$, while the values of the other groups were smaller than those showed by the above authors (Russell and Franca 1995).

Table 1 - Biometric parameters of Wistar rats with colon cancer, submitted, or not, to swimming exercise (means \pm SD).

\begin{tabular}{|c|c|c|c|c|c|}
\hline Parameters & CG & nEG & EG0 & EG2 & EG4 \\
\hline Body (g) & $590 \pm 20^{\mathrm{a}}$ & $403 \pm 26^{\mathrm{b}}$ & $418 \pm 17^{b}$ & $413 \pm 13^{\mathrm{b}}$ & $378 \pm 14^{\mathrm{b}}$ \\
\hline Testis (g) & $1.33 \pm 0.05^{\mathrm{a}}$ & $1.03 \pm 0.05^{\mathrm{b}}$ & $1.14 \pm 0.03^{\mathrm{b}}$ & $1.12 \pm 0.035^{\mathrm{b}}$ & $1.14 \pm 0.07^{\mathrm{b}}$ \\
\hline Testicular parenchyma (g) & $1.27 \pm 0.05^{\mathrm{a}}$ & $0.97 \pm 0.05^{\mathrm{b}}$ & $1.08 \pm 0.03^{\mathrm{b}}$ & $1.07 \pm 0.035^{\mathrm{b}}$ & $1.09 \pm 0.07^{\mathrm{b}}$ \\
\hline Albuginea (g) & $0.059 \pm 0.004$ & $0.058 \pm 0.003$ & $0.059 \pm 0.003$ & $0.056 \pm 0.003$ & $0.058 \pm 0.004$ \\
\hline Epididymis (g) & $0.37 \pm 0.06^{\mathrm{a}}$ & $0.46 \pm 0.03^{\mathrm{b}}$ & $0.51 \pm 0.007^{\mathrm{b}}$ & $0.48 \pm 0.02^{\mathrm{b}}$ & $0.46 \pm 0.03^{\mathrm{b}}$ \\
\hline GSI* $(\%)$ & $0.45 \pm 0.01^{\mathrm{a}}$ & $0.52 \pm 0.02^{\mathrm{ab}}$ & $0.56 \pm 0.03^{\mathrm{b}}$ & $0.55 \pm 0.02^{\mathrm{b}}$ & $0.61 \pm 0.04^{\mathrm{b}}$ \\
\hline
\end{tabular}

CG: control group; nEG: DMH injections, without exercise. EG0: DMH injections + swimming, without load; EG2: DMH injections + swimming with load of $2 \%$ of body mass; EG4: DMH injections + swimming with load of $4 \%$ of body mass.

* Gonadossomatic index. In each row, values with different superscript letters are significantly different $(\mathrm{p}<0.05)$ according to Duncan's test. 
Table 2 - Morphometric and stereological parameters of parenchyma elements of Wistar rats with colon cancer, submitted, or not, to swimming exercise (means $\pm \mathrm{SD}$ ).

\begin{tabular}{|c|c|c|c|c|c|}
\hline Parameters & CG & nEG & EG0 & EG2 & EG4 \\
\hline Seminiferous tubule $(\%)$ & $89.22 \pm 0.94$ & $90.84 \pm 2.65$ & $89.72 \pm 1.67$ & $90.21 \pm 1.77$ & $90.29 \pm 1.35$ \\
\hline Interstitial tissue (\%) & $10.78 \pm 0.94$ & $9.16 \pm 2.65$ & $10.28 \pm 1.67$ & $9.79 \pm 1.77$ & $9.71 \pm 1.35^{\mathrm{a}}$ \\
\hline Seminiferous tubule (mL) & $1.14 \pm 0.04^{\mathrm{a}}$ & $0.88 \pm 0.04^{\mathrm{b}}$ & $0.97 \pm 0.03^{\mathrm{b}}$ & $0.96 \pm 0.035^{\mathrm{b}}$ & $1.00 \pm 0.05^{\mathrm{b}}$ \\
\hline Interstitial tissue (mL) & $0.137 \pm 0.008^{\mathrm{a}}$ & $0.091 \pm 0.01^{\mathrm{b}}$ & $0.110 \pm 0.005^{\mathrm{b}}$ & $0.104 \pm 0.005^{\mathrm{b}}$ & $0.101 \pm 0.007^{b}$ \\
\hline TSI* $(\%)$ & $0.39 \pm 0.01^{\mathrm{a}}$ & $0.45 \pm 0.02^{\mathrm{ab}}$ & $0.47 \pm 0.03^{\mathrm{b}}$ & $0.47 \pm 0.02^{\mathrm{b}}$ & $0.52 \pm 0.03^{\mathrm{b}}$ \\
\hline Epithelium & $110.4 \pm 1.81^{\mathrm{a}}$ & $100.1 \pm 2.34^{\mathrm{b}}$ & $101.16 \pm 1.57^{\mathrm{b}}$ & $97.48 \pm 1.69^{\mathrm{b}}$ & $101.3 \pm 1.71^{\mathrm{b}}$ \\
\hline Tubular & $326.9 \pm 16.4$ & $340.7 \pm 26.0$ & $344.1 \pm 20.9$ & $324.1 \pm 15.6$ & $339.2 \pm 16.3$ \\
\hline Total Tubular Length (m) & $27.19 \pm 1.23^{\mathrm{a}}$ & $19.44 \pm 0.88^{b}$ & $20.94 \pm 0.64^{\mathrm{bc}}$ & $23.32 \pm 0.54^{\mathrm{c}}$ & $21.61 \pm 0.90^{\mathrm{bc}}$ \\
\hline $\begin{array}{l}\text { Tubular Length per gram } \\
\text { of testis (m) }\end{array}$ & $10.70 \pm 1.30$ & $10.14 \pm 1.78$ & $9.76 \pm 1.22$ & $10.99 \pm 0.96$ & $10.04 \pm 0.92$ \\
\hline
\end{tabular}

CG: control group; nEG: DMH injections, without exercise. EG0: DMH injections + swimming, without load; EG2: DMH injections + swimming with load of $2 \%$ of body mass; EG4: DMH injections + swimming with load of $4 \%$ of body mass. * Tubule-somatic index. In each row, values with different superscript letters are significantly different $(p<0.05)$ according to Duncan's test.

The number of round spermatids, spermatocytes in preleptotene and pachytene, and total number of the germ line cell were reduced in the groups with colon cancer when compared to the control, except for the group that exercised without load. All the counts in this group (EG0) were similar when compared to the controls (Table 3). These results clearly indicated that colon cancer caused real spermatogenesis impairment; on the other hand they also showed that long-term swimming exercise (mainly without load) could prevent the damage caused by colon cancer to the testis.

Table 3 - Number of germ line cells, mitotic yield (preleptotene spermatocytes / spermatogonia A), meiotic yield (round spermatids / pachytene spermatocytes) and, spermatogenesis yield (round spermatids / spermatogonia A) of Wistar rats that received DMH-injections, submitted or not to swimming exercise (means \pm SD).

\begin{tabular}{lccccc}
\hline Parameters & CG & nEG & EG0 & EG2 & EG4 \\
\hline $\begin{array}{l}\text { Spermatogonias A } \\
\text { Preleptotene }\end{array}$ & $1.62 \pm 0.42^{\mathrm{a}}$ & $1.59 \pm 0.19^{\mathrm{ab}}$ & $1.48 \pm 0.28^{\mathrm{ab}}$ & $1.28 \pm 0.38^{\mathrm{b}}$ & $1.65 \pm 0.34^{\mathrm{a}}$ \\
Spermatocytes & $25.84 \pm 2.92^{\mathrm{a}}$ & $23.27 \pm 1.63^{\mathrm{bc}}$ & $25.27 \pm 2.23^{\mathrm{ac}}$ & $22.65 \pm 1.99^{\mathrm{b}}$ & $21.14 \pm 1.89^{\mathrm{b}}$ \\
$\begin{array}{l}\text { Pachytene } \\
\text { spermatocytes }\end{array}$ & $34.20 \pm 4.38^{\mathrm{a}}$ & $28.38 \pm 4.45^{\mathrm{b}}$ & $32.72 \pm 3.27^{\mathrm{ac}}$ & $29.63 \pm 2.34^{\mathrm{bc}}$ & $28.39 \pm 3.38^{\mathrm{b}}$ \\
$\begin{array}{l}\text { Round spermatids } \\
\text { Germ cell total }\end{array}$ & $73.26 \pm 9.17^{\mathrm{a}}$ & $63.56 \pm 7.07^{\mathrm{bc}}$ & $68.87 \pm 5.59^{\mathrm{ac}}$ & $61.98 \pm 5.13^{\mathrm{b}}$ & $60.42 \pm 6.02^{\mathrm{b}}$ \\
number & $134.93 \pm 15.99^{\mathrm{a}}$ & $116.80 \pm 12.63^{\mathrm{b}}$ & $128.34 \pm 10.61^{\mathrm{a}}$ & $115.54 \pm 8.66^{\mathrm{b}}$ & $111.60 \pm 10.65^{\mathrm{b}}$ \\
$\begin{array}{l}\text { Mitotic yield } \\
\text { Meiotic yield }\end{array}$ & $16.75 \pm 4.05^{\mathrm{ac}}$ & $14.83 \pm 2.23^{\mathrm{ab}}$ & $17.51 \pm 3.19^{\mathrm{a}}$ & $19.24 \pm 6.18^{\mathrm{c}}$ & $13.23 \pm 2.66^{\mathrm{ab}}$ \\
$\begin{array}{l}\text { Spermatogenesis } \\
\text { yield }\end{array}$ & $2.15 \pm 0.11^{\mathrm{ab}}$ & $2.27 \pm 0.21^{\mathrm{a}}$ & $2.11 \pm 0.09^{\mathrm{ab}}$ & $2.09 \pm 0.12^{\mathrm{b}}$ & $2.14 \pm 0.18^{\mathrm{ab}}$ \\
\hline
\end{tabular}

CG: control group; nEG: DMH injections, without exercise. EG0: DMH injections + swimming, without load; EG2: DMH injections + swimming with load of $2 \%$ of body mass; EG4: DMH injections + swimming with load of $4 \%$ of body mass. In each row, values with different superscript letters are significantly different $(\mathrm{p}<0.05)$ according to Duncan's test.

Exercise is known to cause some testicular impairment (Manna et al. 2003; Manna et al. 2004; Hackney 2008; Jana et al. 2008). Mingoti et al. (2003) observed that high-intensity swimming stress caused a significant reduction in the number of spermatids in seminiferous tubules of Wistar rats. So, the reduction in the quantity of round spermatids, preleptotene and pachytene spermatocytes, the loss of SC support capacity and efficiency with the increase of swimming exercise load could be related to the increase of stress caused by load increase.

The DMH-treated animals showed a widely heterogeneous response in testicular tissue, ranging from isolated spots displaying partially impaired seminiferous tubules to a generalized impairment all over the testis (Fig. 1). Also, a few seminiferous tubules showed a total lack of spermatogenic cells, being lined only with the Sertoli cells. Those histopathological alterations in 
the seminiferous tubules are caused by the degeneration and loss of germ cells. The germ cells are entirely dependent on the coordinated functioning of all other cell types and processes within the testis, and any disturbance of their environment generally results in their death upon exfoliation into the tubular lumen (Creasy 1997). Therefore, the histopathological alterations observed confirmed that the testicular function depended on cell-cell interaction. The different degrees of atrophy of the testes within each group were due to differences in sensitivity of the rats to the colon cancer caused impairment and exercise stress.

The interstitial tissue of rat testes comprised blood vessels, Leydig cells, lymphatic space, macrophages and connective tissue (Fawcett et al. 1973; Russell and Franca 1995). Interstitial tissue volume reduction observed in the colon cancer groups was due to reduction of lymphatic space and connective tissue volume (Tables 2 and 4). Lymphatic space reduction could be related to the problems of testosterone transport to seminiferous tubules, since the lymphatic space surrounded the blood vessels and LC clusters bridging testosterone sources (directly from the LC, or from the bloodstream) and seminiferous tubules (Fawcett et al. 1973; Foley 2001). The lymphatic space volume reduction could also impair the nutrient transport from the blood vessels to the seminiferous tubules (Fawcett et al. 1973; Foley 2001).
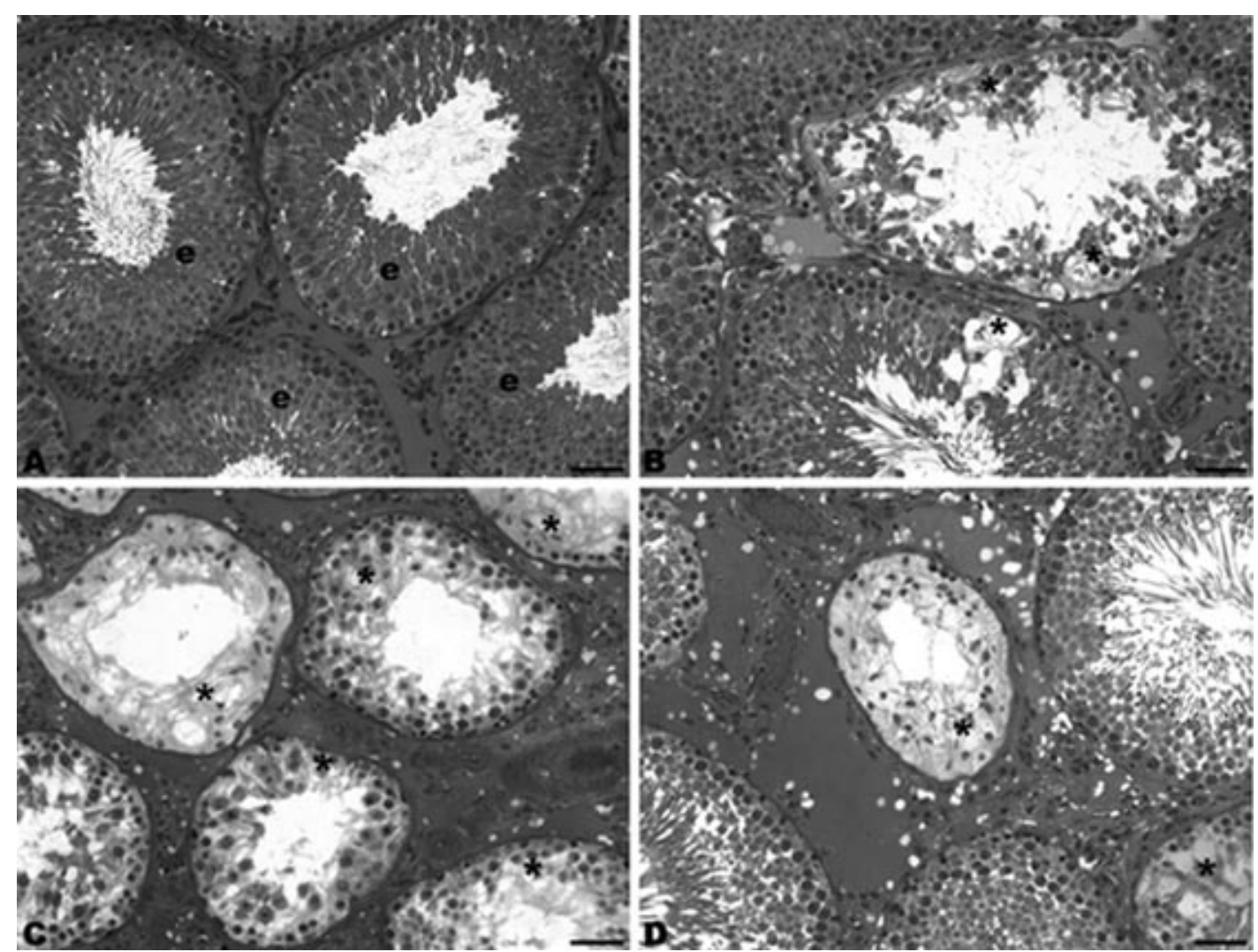

Figure 1 - Micrographs of Wistar rats' testis, toluidine blue/1\% sodium borate stained. A is a normal testis, from the control group, in this image there is no alteration on the typical germ epithelium (e) structure. B, C and D are micrographs of testes of animals that received DMH-injections and were exercised, or not, (groups EG4, EG2 and nEG respectively), the asterisks indicate regions with different intensities of seminiferous tubule degeneration. Bars $=50 \mu \mathrm{m}$. Magnification 200x. 


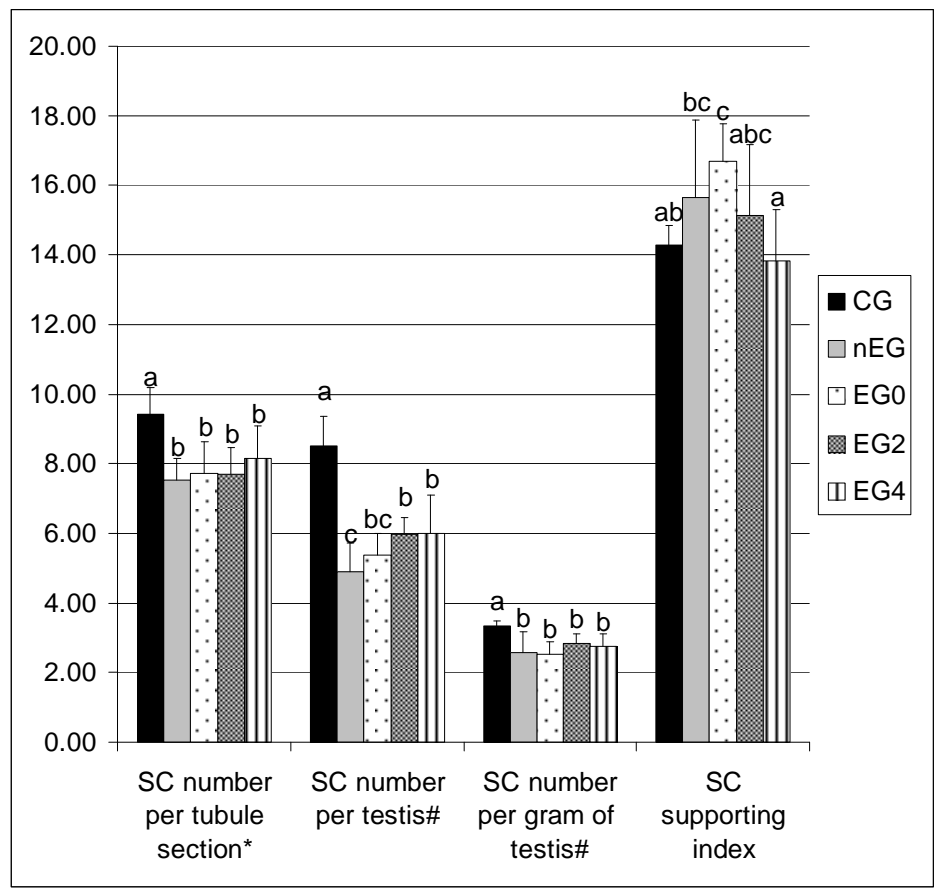

Figure 2 - Number of Sertoli cells (SC) per tubule in stage I sections (*), testis and gram of testis (\# indicates that the values are $\times 10^{7}$ ), and SC supporting index. CG: control group; nEG: DMH injections, without exercise. EG0: DMH injections + swimming, without load; EG2: DMH injections + swimming with load of $2 \%$ of body mass; EG4: DMH injections + swimming with load of $4 \%$ of body mass. In each bar, values with different superscript letters are significantly different $(\mathrm{p}<0.05)$.

Damage caused on the LC bythe colon cancer induced with DMH-injections was not observed, as shown by the morphometry and stereology (Table 4). Castro et al. (2002) observed a significant correlation among the testosterone levels and LC number per testis and the percentage of nuclei of these cells. So, results found in this study could indicate that the colon cancer induced by the DMH-injections did not cause drastic changes in the testosterone production. On the other hand, an increase in the LC volume per testis and per gram of testis in the EG0 group was observed when compared to the control (Table 4). This result could be related to LC improvement caused by the exercise.

Table 4 - Stereology of testis intertubular compartment elements of Wistar rats that received DMH-injections, submitted, or not, to swimming exercise (means \pm SD).

\begin{tabular}{|c|c|c|c|c|c|}
\hline Parameters & CG & nEG & EG0 & EG2 & EG4 \\
\hline \multicolumn{6}{|c|}{ Volume per testis $\left(x 10^{-2}\right)(\mathrm{mL})$} \\
\hline Limphatic space & $7.2 \pm 0.68^{\mathrm{a}}$ & $3.4 \pm 0.88^{\mathrm{b}}$ & $3.5 \pm 0.42^{\mathrm{b}}$ & $3.2 \pm 0.60^{\mathrm{b}}$ & $3.6 \pm 0.74^{\mathrm{b}}$ \\
\hline Connective tissue & $0.96 \pm 0.17^{\mathrm{a}}$ & $0.59 \pm 0.07^{\mathrm{b}}$ & $0.63 \pm 0.07^{\mathrm{b}}$ & $0.70 \pm 0.09^{\mathrm{b}}$ & $0.59 \pm 0.07^{\mathrm{b}}$ \\
\hline Macrophages & $0.41 \pm 0.04^{\mathrm{a}}$ & $0.14 \pm 0.02^{\mathrm{b}}$ & $0.32 \pm 0.03^{\mathrm{a}}$ & $0.35 \pm 0.05^{\mathrm{a}}$ & $0.35 \pm 0.06^{\mathrm{a}}$ \\
\hline Leydig Cells & $3.88 \pm 0.64^{\mathrm{a}}$ & $3.87 \pm 0.37^{\mathrm{a}}$ & $5.51 \pm 0.33^{\mathrm{b}}$ & $4.68 \pm 0.34^{\mathrm{ab}}$ & $4.39 \pm 0.58^{\mathrm{ab}}$ \\
\hline \multicolumn{6}{|c|}{ Volume per gram of testis $\left(x 10^{-2}\right)(\mathrm{mL})$} \\
\hline Limphatic space & $5.48 \pm 0.61^{\mathrm{a}}$ & $3.17 \pm 0.75^{\mathrm{b}}$ & $3.09 \pm 0.37^{\mathrm{b}}$ & $2.85 \pm 0.54^{\mathrm{b}}$ & $3.05 \pm 0.53^{b}$ \\
\hline Connective tissue & $0.72 \pm 0.13$ & $0.57 \pm 0.06$ & $0.57 \pm 0.08$ & $0.62 \pm 0.07$ & $0.50 \pm 0.05$ \\
\hline Macrophages & $0.30 \pm 0.03^{\mathrm{a}}$ & $0.14 \pm 0.02^{\mathrm{b}}$ & $0.27 \pm 0.03^{\mathrm{a}}$ & $0.31 \pm 0.04^{\mathrm{a}}$ & $0.31 \pm 0.05^{\mathrm{a}}$ \\
\hline Leydig Cells & $2.86 \pm 0.39^{\mathrm{a}}$ & $3.74 \pm 0.31^{\mathrm{ab}}$ & $4.83 \pm 0.25^{\mathrm{b}}$ & $4.23 \pm 0.42^{\mathrm{b}}$ & $3.95 \pm 0.58^{\mathrm{ab}}$ \\
\hline
\end{tabular}

CG: control group; nEG: DMH injections, without exercise. EG0: DMH injections + swimming, without load; EG2: DMH injections + swimming with load of $2 \%$ of body mass; EG4: DMH injections + swimming with load of $4 \%$ of body mass. In each row, values with different superscript letters are significantly different $(\mathrm{p}<0.05)$ according to Duncan's test 
Macrophages are related to steroidogenesis control by the release of stimulatory and inhibitory factors that have paracrine effects on LC (Hutson 1998). Furthermore, there is an intimate relationship between the macrophages and $\mathrm{LC}$, where $\mathrm{LC}$ are responsible for the production of mitotic agents capable of regulating macrophage proliferation (Hutson 1998). So, the reduction in the macrophage volume only in the group $\mathrm{nEG}$, when compared with the others (Table 4) could indicate a possible injury caused by the colon cancer that was attenuated by the swimming exercise.

Despite being not statistically significant, the testicular and testicular parenchyma weights were slightly increased in the groups EG0, EG2 and EG4 when compared to $\mathrm{nEG}(9.65 \%, 8.64 \%$ and $9.65 \%$, respectively for testicular weight and $10.18,9.35$ and $11.01 \%$, respectively, for parenchyma testicular weight) (Table 1). Similar results were observed for the seminiferous tubules and interstitial tissue volume and total seminiferous tubule length (Table 2). The LC volume per testis and per gram of testis also increased in the groups EG0, EG2 and EG4 when compared with $\mathrm{nEG}$ (increased 29.76, 17.31 and $11.84 \%$, respectively for the volume per testis and 22.57, 11.58 and $5.32 \%$, respectively for the volume per gram of testis) (Table 4). Although not significant, these results added to those for macrophage volume could indicate that the longterm swimming program used here had a small protective effect against the damage caused by the DMH-induced colon cancer in the testis.

The alterations observed in the testis of the animals that received the DMH-injections could be due to toxic effects of DMH-injections, or to the development of colon cancer. Possibly, the hypermethylation caused by the DMH affected Sertoli or/and germ cells, culminating in the results obtained. However, the drug was administered at the beginning of the long treatment of the rats, and if the drug had caused initial damage to the testis, the tissue would have been either totally destroyed, or recuperating. Assuming that the development of colon cancer caused the observed impairment, there were three possible explanations. First, colon cancer could cause testicular metastasis (Almagro 1988; Meacham et al. 1988), but the rats that received DMHinjections did not have metastatic tissue in their testes, which suggested that this hypothesis was not adequate. Second, the testicular damage could be due to cancer-induced cachexia (Ockenga and Valentini 2005; Silva 2006). Nutrient restriction could harm spermatogenesis. Howland (1975) observed that the rats restricted to $50 \%$ of normal feed intake during 20 days had a reduction of serum testosterone. This reduction of testosterone levels could result in the impairment of spermatogenesis. And finally, there might be some unknown pathway activated by the cancer cells that could affect the testicular cell functions. The results observed in the present study could be related to an interaction of these factors. Despite the structural alterations observed for LC, the function of these cells was not analyzed.

Long-term swimming training with different loads did not protect against the DMH-induced tumor incidence, multiplicity (tumor per animal), or tumor size in Wistar rats, but, swimming training with a load of $2 \%$ body weight was efficient to protect against the preneoplastic lesions (Lunz et al. 2008). Nevertheless, the same swimming program was not efficient to reduce the testicular damage caused by the colon cancer, although there was a slight improvement of the testes structure of the group exercised without load.

\section{CONCLUSIONS}

This study revealed that the DMH-induced colon cancer caused serious damage to the testicular structure what could culminate in the reduction of the rats `ertility. The swimming exercise without a load slightly reduced the damage caused by the colon cancer. It would an important step to develop, in the future, a way to avoid the fertility impairment associated with the colon cancer.

\section{ACKNOWLEDGMENTS}

We thank the students of "Laboratório de Biologia Reprodutiva e Microscopia Eletrônica", IB/Unicamp, for reviewing this manuscript, as well as the Conselho Nacional de Desenvolvimento Científico e Tecnológico (CNPq) and CAPES (CAPES-PROF/UFV) for financial support. 


\section{REFERENCES}

Almagro UA. Metastatic tumors involving testis. Urology. 1988; 32(4): 357-360.

Amann RP, Almquist JO. Reproductive Capacity of Dairy Bulls. VIII. Direct and Indirect Measurement of Testicular Sperm Production. J Dairy Sci. 1962; 45(6): 774-781.

Amann RP, Schanbacher BD. Physiology of male reproduction. J Anim Sci. 1983; 57 Suppl 2: 380-403.

Attal J, Courot M. Developpement testiculaire et etablissement de la spermatogeneses chez le taureau. Ann Biol Anim Biochim Biophys. 1963; 3: 219-241.

Castro AC, Berndtson WE, Cardoso FM. Plasma and testicular testosterone levels, volume density and number of Leydig cells and spermatogenic efficiency of rabbits. Braz J Med Biol Res. 2002; 35(4): 493498.

Costa KL, Matta SL, Gomes MLM, Paula TA, Freitas KM, Carvalho FAR, et al. Histomorphometric evaluation of the neotropical brown brocket deer Mazama gouazoubira testis, with an emphasis on cell population indexes of spermatogenic yield. Anim Reprod Sci. 2011; 127(3-4): 202-212.

Cotran RS, Kumar V, Robbins SL. Patologia estrutural e funcional. 5 ed. Rio de Janeiro: Guanabara Koogan; 1996. 1277 p.

Creasy DM. Evaluation of testicular toxicity in safety evaluation studies: the appropriate use of spermatogenic staging. Toxicol Pathol. 1997; 25(2): 119-131.

Curtis SK, Amann RP. Testicular development and establishment of spermatogenesis in Holstein bulls. $J$ Anim Sci. 1981; 53(6): 1645-1657.

Demarzo MM, Garcia SB. Exhaustive physical exercise increases the number of colonic preneoplastic lesions in untrained rats treated with a chemical carcinogen. Cancer Lett. 2004; 216(1): 31-34.

Demarzo MM, Martins LV, Fernandes CR, Herrero FA, Perez SE, Turatti A, et al. Exercise reduces inflammation and cell proliferation in rat colon carcinogenesis. Med Sci Sports Exerc. 2008; 40(4): 618-621.

Dorst VJ, Sajonski H. Morphometrische untersuchunhen am tubulussystem des schweinehodens während der postnatalen entwicklug. Mon Vert Med. 1974; 29: 650-652.

Fawcett DW, Neaves WB, Flores MN. Comparative observations on intertubular lymphatics and the organization of the interstitial tissue of the mammalian testis. Biol Reprod. 1973; 9(5): 500-532.

Foley GL. Overview of male reproductive pathology. Toxicol Pathol. 2001; 29(1): 49-63.

França LR. Análise morfofuncional da espermatogênese de suínos adultos da raça Piau [PhD thesis]. Belo Horizonte: Universidade Federal de Minas Gerais; 1991.
Freitas KM, Costa KL, Campos PKA, Melo FCSA, Paula TAR, Matta SLP. Effects of catuaba cristal® on the testis of wistar rats. Braz Arch Biol Technol. 2011; 54: 901-906.

Friedenreich CM, Orenstein MR. Physical activity and cancer prevention: etiologic evidence and biological mechanisms. J Nutr. 2002; 132(11 Suppl): 3456S3464S.

Gomes MLM, Monteiro JC, Freitas KM, Sbervelheri MM, Dolder H. Association of the infusion of Heteropterys aphrodisiaca and endurance training brings spermatogenetic advantages. Biol Res. 2011; 44: 235-241.

Hackney AC. Effects of endurance exercise on the reproductive system of men: the "exercisehypogonadal male condition". J Endocrinol Invest. 2008; 31(10): 932-938.

Harriss DJ, Atkinson G, Batterham A, George K, Cable NT, Reilly $\mathrm{T}$, et al. Lifestyle factors and colorectal cancer risk (2): a systematic review and meta-analysis of associations with leisure-time physical activity. Colorectal Dis. 2009; 11(7): 689-701.

Hochereau-de Reviers MT, Lincoln GA. Seasonal variation in the histology of the testis of the red deer, Cervus elaphus. J Reprod Fertil. 1978; 54(2): 209213.

Hoffman-Goetz L. Physical activity and cancer prevention: animal-tumor models. Med Sci Sports Exerc. 2003; 35(11): 1828-1833.

Howland BE. The influence of feed restriction and subsequent re-feeding on gonadotrophin secretion and serum testosterone levels in male rats. J Reprod Fertil. 1975; 44(3): 429-436.

Jana K, Samanta PK, Manna I, Ghosh P, Singh N, Khetan RP, et al. Protective effect of sodium selenite and zinc sulfate on intensive swimming-induced testicular gamatogenic and steroidogenic disorders in mature male rats. Appl Physiol Nutr Metab. 2008; 33(5): 903-914.

Pais JMJ, Castanon LB, Lopez AB, Diaz-Reixa JP, Selas RE, Agudo VPC et al. Metastasis of colon adenocarcinoma to the epididymis and spermatic cord]. Arch Esp Urol. 2006; 59(7): 746-748.

Kanno K, Ohwada S, Nakamura S, Ohya T, Iino Y, Morishita Y, et al. Epididymis metastasis from colon carcinoma: a case report and a review of the Japanese literature. Jpn J Clin Oncol. 199; 24(6): 340-344.

Russell LD, Franca LR. Building a testis. Tissue Cell. 1995; 27(2): 129-147.

Leite R, Wada R, Monteiro J, Predes F, Dolder H. Protective Effect of Guaraná (Paullinia cupana var. sorbilis) Pre-treatment on Cadmium-Induced Damages in Adult Wistar Testis. Biol Trace Elem Res. 2010; 141: 262-274.

Lunz W. Interferência do Treinamento em Natação com Diferentes Intensidades na Carcinogênese Experimental do Cólon [Dissertation]: Universidade Federal de Viçosa; 2006. 
Lunz W, Peluzio MC, Dias CM, Moreira AP, Natali AJ. Long-term aerobic swimming training by rats reduces the number of aberrant crypt foci in 1,2dimethylhydrazine-induced colon cancer. Braz J Med Biol Res. 2008; 41(11): 1000-1004.

Manna I, Jana K, Samanta PK. Effect of intensive exercise-induced testicular gametogenic and steroidogenic disorders in mature male Wistar strain rats: a correlative approach to oxidative stress. Acta Physiol Scand. 2003; 178(1): 33-40.

Manna I, Jana K, Samanta PK. Effect of different intensities of swimming exercise on testicular oxidative stress and reproductive dysfunction in mature male albino Wistar rats. Indian J Exp Biol. 2004; 42(8): 816-822.

Meacham RB, Mata JA, Espada R, Wheeler TM, Schum CW, Scardino PT. Testicular metastasis as the first manifestation of colon carcinoma. J Urol. 1988; 140(3): 621-622.

Mingoti GZ, Pereira RN, Monteiro CM. Fertility of male adult rats submitted to forced swimming stress. Braz J Med Biol Res. 2003; 36(5): 677-681.

Moreno AK, Sastre VJ, Loboff LB, López-Tarruella S, Ortega ML, Dias-Rubio E. Epididymal metastases as the first sign of a colon cancer recurrence. Clin Transl Oncol. 2005; 7(7): 321-323.
Monteiro J, Predes F, Matta S, Dolder H. Heteropterys aphrodisiaca infusion reduces the collateral effects of cyclosporine A on the testis. Anat Rec (Hoboken). 2008; 291(7): 809-17.

Ockenga J, Valentini L. Review article: anorexia and cachexia in gastrointestinal cancer. Aliment Pharmacol Ther. 2005; 22(7): 583-594.

Predes F, Monteiro J, Matta S, Garcia M, Dolder H. Testicular Histomorphometry and Ultrastructure of Rats Treated with Cadmium and Ginkgo biloba. Biol Trace Elem Res. 2011;140(3): 330-341.

Silva MPN. Síndrome da anorexia-caquexia em portadores de cancer. Rev Bras Cancerol. 2006; 52(1): 59-77.

Swierstra EE. A comparison of spermatozoa production and spermatozoa output of Yorkshire and Lacombe boars. J Reprod Fertil. 1968; 17(3): 459-469.

Received: March 21, 2012; Accepted: May 09, 2013. 